\section{Адриан Барентсен}

Амстердамский университет

Филологический факультет

Амстердамский центр исследования языка и коммуникации

Группа по сравнительному изучению славянского вида

(и смежных вопросов)

a.barentsen@xs4all.nl

\section{Виктор С. Храковский}

Институт лингвистических исследований РАН Лаборатория типологического изучения языков khrakovv@gmail.com
УДК 811.16 '367

https://doi.org/10.18485/slavistika.2020.24.2.1

оригинални научни рад примљено 16.08.2020. прихваћено за штампу 18.09.2020.

\title{
О ВТОРИЧНЫХ ЗНАЧЕНИЯХ ТАКСИСНЫХ СОЮЗОВ ПРЕДШЕСТВОВАНИЯ В СЛАВЯНСКИХ ЯЗЫКАХ
}

Статья опирается на гипотезу, что среди сирконстантных союзов временны́е (таксисные) являются первичными и в силу этого обладают потенцией приобретать вторичные причинные и/или условные значения. В большинстве южнославянских языков такие вторичные значения есть у отдельных специализированных союзов предшествования, типа как только или после того как. Наличие вторичных значений у этих союзов в сербском, хорватском, македонском и болгарском языках подтверждается примерами из параллельных текстов, которые фиксируют определенные различия между этими языками в частотности употребления таксисных союзов с вторичными значениями.

Ключевые слова: временные (таксисные) союзы, предшествование, расширение значения, причинное и условное значение, южнославянские языки, сопоставительный анализ.

The article is based on the hypothesis that among the conjunctions introducing subordinate adverbial clauses, the temporal (taxis) conjunctions are primary and therefore have the potential to acquire secondary causal and/or conditional meanings. In most of the South Slavic languages such an expansion of meaning is found with one or more specialized conjunctions of anteriority like as soon as or after. The presence of secondary meanings with these conjunctions in Serbian, Croatian, Macedonian and Bulgarian is confirmed by examples from parallel texts that also demonstrate certain differences between these languages in frequency of the taxis conjunctions in such cases.

Keywords: temporal (taxis) conjunctions, anteriority, expansion of meaning, causal and conditional meaning, South Slavic languages, contrastive analysis.

\section{1. Введение}

В славянских языках, как и в других языках мира, значения функционально-семантической категории таксиса, а именно 'предшествование', 'одновременность' и 'следование', реализуются с помощью различных формальных средств. Это, в частности, бипредикативные сложноподчиненные временные предложения, предложения с деепричастными и причастными оборотами, а также предложения с отглагольными именами действия, подробнее см. (Храковский 2009). Ведущим средством выражения таксисных значений в славянских языках являются сложноподчиненные временные предложения (СПП). В этих предложениях глагол в придаточной части (ПЧ) обозначает ситуацию, 
которая либо предшествует, либо одновременна, либо следует за ситуацией, выражаемой глаголом в главной части (ГЧ) предложения. ПЧ таких предложений вводится одним из союзов, которые бывают неспециализированные и специализированные.

К числу неспециализированных союзов относится, например, русский союз когда и аналогичные союзы в других славянских языках. Подобные союзы могут маркировать разные таксисные значения вместе с различными комбинациями видовременных глагольных форм в ПЧ и ГЧ предложения. Специализированным союзом является, например, русский союз как только и аналогичные союзы в других славянских языках. Подобные союзы маркируют либо одно, либо (редко) два таксисных значения. Союз как только, например, маркирует то, что ситуация, обозначаемая глаголом в ПЧ предложения, непосредственно предшествует ситуации, обозначаемой глаголом в ГЧ предложения, например:

(1) Как только я вошел в вагон, поезд тронулся.

Временные СПП входят в группу сложноподчиненных предложений, в которых союзы вводят ПЧ, выполняющую роль сирконстанта ГЧ. В эту группу наряду с временными обычно включаются, причинные, целевые, условные и уступительные предложения. В свою очередь временные предложения противопоставляются всем остальным, которым приписывается значение логической обусловленности или просто обусловленности, см. например (Князев 2007; Евтюхин 1996). ${ }^{1}$

Есть основания полагать, что в приведенной последовательности предложений каждый следующий элемент на определенный смысл сложнее предшествующего элемента и (в какой-то мере) наследует смысл предшествующего элемента/предшествующих элементов. При этом степень их семантической сложности коррелирует с последовательностью их появления в речи ребенка, cp. (Givón 1990). Соответственно временные, точнее таксисные СПП с семантической точки зрения проще всех остальных сирконстантных предложений, и при этом их семантика, как было установлено в работе (Храковский 2009) в том или ином варианте представлена во всех остальных сирконстантных СПП. Кроме того, мы учитываем и то, что временные СПП, очевидно, первыми из перечисленных СПП начинают регулярно появляться в речи ребенка, овладевающего речью (Сударева 2007: 96), а остальные начинают появляться в речи ребенка позже, в указанной выше последовательности.

На справедливость высказанного предположения указывает и тот факт, что союзы, используемые во временных СПП, обладают потенциальной способностью получать вторичные причинные и условные значения. Известным примером этого является английский союз since, который может выражать таксисное значение 'с тех пор как', но также очень широко употребляется для выражения значения причины 'поскольку, так как'. Ср. следующие примеры из книги The Hobbit Толкина:

${ }^{1}$ Для обозначения СПП логической обусловленности используется также термин ‘импликативная конструкция', см. (Подлесская 1995). 
(2) $[\mathrm{H}] \mathrm{e}$ had forgotten everything that had happened since they started their journey. 'Он забыл обо всем, что случилось с тех пор, как они начали свое путешествие.'

(3) There was a lot here which Smaug did not understand at all (though I expect you do, since you know all about Bilbo's adventures to which he was referring) $[\ldots]$

'Здесь было много такого, чего Смауг совсем не понял (хотя я подозреваю, что вы понимаете, поскольку знаете о приключениях Бильбо, на которые он намекал) [...]'

Такое расширенное значение союзов со специализированным таксисным значением типа 'с тех пор как' в славянских языках не наблюдается. Однако аналогичное вторичное значение таксисных союзов предшествования пошто ‘после того как' и чим 'как только' в сербском языке было отмечено в работе (Поповић 2014: 132-137; 152). Там же отмечается важный факт, что при выражении нетемпорального значения у этих союзов «фоновым» таксисным значением обычно является не предшествование, а одновременность. В коллективной монографии Таксис в славянских языках, которую мы в настоящий момент редактируем, приводятся данные о наличии аналогичного вторичного значения у таксисных союзов предшествования еще и в двух других южнославянских языках - македонском и болгарском.

Ниже мы рассматриваем это явление в сопоставительном плане, на конкретном материале Амстердамского параллельного корпуса (ASPAC). Исходным материалом служат 23 текста с их переводами на сербский, хорватский, македонский и болгарский языки. ${ }^{2}$ Для сравнения учитываются также переводы на русский, польский и словенский. ${ }^{3}$ Примеры с вторичными значениями есть в большинстве текстов, некоторые из них приводятся в статье. Преимущественно это примеры из переводов романов Михаила Булгакова (Мастер и Маргарита) и Станислава Лема (Solaris), это наши «исходные тексты».

В следующей таблице дается обзор специализированных союзов указанных двух групп. Поскольку в примерах встречаются также основные неспециализированные союзы типа русского 'когда', они также представлены в схеме. Союзы, рассматриваемые ниже, выделены жирным шрифтом. В квадратных скобках указано количество примеров этих союзов в нашем материале.

\footnotetext{
${ }^{2}$ Сведения об этих текстах приводятся в конце статьи. Хорватский язык, близкородственный с сербским, в упомянутой монографии не представлен. Мы рассматриваем его здесь, поскольку вопрос о возможных различиях между близкороственными языками нам представляется важным.

${ }^{3}$ Словенский материал важен для выявления того, насколько рассматриваемое явление охватывает всю южнославянскую группу.
} 


\section{Специализированные союзы предшествования:}

Русский:

Польский:

Словенский:

Хорватский:

Сербский: 4

Македонский:

Болгарский: 'как только'

как только

jak tylko / skoro tylko

čim / brž ko

čim [333] / tek što

чим [359] / тек ито

штом [435] / тукуито

щем [795] 'после того как'

после того как

po tym jak/kiedy/gdy

potem ko

pošto [370] / nakon što

noumo [810] / nakon što

откако ${ }^{5}[980] /$ откога

след като [781]

\section{Основной неспециализированный союз:}

Русский:

Польский:

Словенский:

Хорватский:

Сербский:

Македонский:

Болгарский: когда

kiedy / gdy

ko

$\operatorname{kad}(a)$

$\kappa a \partial(a)$

кога

когато

\section{2. Рассмотрение параллельных примеров}

Ниже приводятся примеры с употреблением рассматриваемых союзов в темпоральном, а затем в нетемпоральном значении.

\section{1. Союзы типа 'как только'}

(4) Булгаков. Союзы с̌іm, цим, итом и щом с темпоральным значением:

\begin{tabular}{|l|l|}
\hline Ру & Я как только глянул на вас, догадался, что это вы! \\
\hline По1 & Jak tylko na pana spojrzałem, od razu domyślitem sie, że to pan! \\
\hline Сн & Samo da sem vas zagledal, pa sem uganil, da ste to vi! \\
\hline Xp & Čim sam vas pogledao, pogodio sam da ste to vi! \\
\hline
\end{tabular}

${ }_{4}^{4}$ Чтобы легче различать хорватские и сербские примеры, ниже сербский вариант всегда будет написан кириллицей, даже в тех случаях, когда в оригинале была латиница.

${ }^{5}$ Македонский союз откако регулярно выражает также значение типа 'с тех пор как'. Например в македонском переводе примера (2). 


\begin{tabular}{|l|l|}
\hline Сб1/26 & Чим сам вас угледао, одмах сам схватио да сте то ви! \\
\hline Мк & Штом ве погледнав, се сетив дека сте тоа вие! \\
\hline Бг & Щом ви видя, и се сетих, че сте именно вие! \\
\hline
\end{tabular}

В данном примере все четыре рассматриваемых союза ясно выражают чисто темпоральное (таксисное) значение контактного предшествования.

(5) Lem. Союзы с̌im, чим с темпоральным значением:

\begin{tabular}{|c|c|}
\hline По & $\begin{array}{l}\text { [Zresztą, jak tylko się zbliżyłem [- dzieliło mnie od niego ze } \\
\text { czterdzieści metrów, może trochę więcej -] zorientowałem się, że jest } \\
\text { w nim coś niedobrego. }\end{array}$ \\
\hline Py & $\begin{array}{l}\text { Как только я приблизился }[. . .] \text { заметил, что в нем есть что-то } \\
\text { нехорошее. }\end{array}$ \\
\hline $\mathrm{CH}_{\mathrm{H}}$ & $\begin{array}{l}{[\ldots] \text { brž ko sem se mu približal }[. . .] \text { sem se zavedel, da je v njem nekaj }} \\
\text { pokvarjenega. }\end{array}$ \\
\hline $\mathrm{Xp}$ & $\begin{array}{l}{[\ldots] \text { čim sam mu se približio }[. . .] \text { shvatio sam da s njime nešto nije u }} \\
\text { redu. }\end{array}$ \\
\hline Сб1/2 & $\begin{array}{l}{[\ldots] \text { чим сам се приближио }[. . .] \text { разабрах да у њему има нешто }} \\
\text { што не ваља. }\end{array}$ \\
\hline Мк & $\begin{array}{l}{[. . .] \text { кога му се приближив }[. . .] \text { сфатив дека во него има нешто }} \\
\text { што не чини. }\end{array}$ \\
\hline Бг & $\begin{array}{l}{[. . .] \text { когато се приближих }[. . .] \text { разбрах, че в него има нещо не }} \\
\text { както трябва. }\end{array}$ \\
\hline
\end{tabular}

В этом примере в македонском и болгарском переводах вместо ожидаемых союзов штом и щзом употребляется неспециализированный таксисный союз типа когда. При глагольных формах совершенного вида такие союзы обычно также выражает (неподчеркнутое) контактное предшествование.

Обратное соотношение выбора неспециализированного и специализированных союзов представлено в следующем примере, где специализированные союзы выбраны только в македонском и болгарском переводах:

(6) Lem. Союзы щцом и откако с темпоральным значением:

\begin{tabular}{|l|l|}
\hline По & $\begin{array}{l}{[\ldots] \text { kiedy kontrolki zapality się po włączeniu głównego obwodu, }} \\
\text { wylazłem z ciasnego wnętrza [i wskazałem je Harey, która stała u } \\
\text { drabinki.] }\end{array}$ \\
\hline Ру & $\begin{array}{l}{[\ldots] \text { когда после включения главной цепи загорелись сигнальные }} \\
\text { лампочки, [я] вылез из тесной кабины }[. . .]\end{array}$ \\
\hline
\end{tabular}

${ }^{6}$ Таким образом указывается, что в обеих переводах употребляется тот же самый союз. 


\begin{tabular}{|l|l|}
\hline Сн & $\begin{array}{l}{[\ldots] \text { in ko so potem, ko se je vključilo glavno napajanje, posvetile }} \\
\text { kontrolne lučke, sem zlezel iz tesne kabine }[. . .]\end{array}$ \\
\hline $\mathrm{Xp}$ & $\begin{array}{l}{[\ldots] \text { a kada su se upalile kontrolne svjetiljke nakon uključenja glavnoga }} \\
\text { reaktora, izašao sam iz tijesne unutrašnjosti }[. . .]\end{array}$ \\
\hline Cб1/2 & $\begin{array}{l}{[. .] \text { а кад ce запалище контролне лампе након укључивања главног }} \\
\text { струјног кола, изиђох из тесног смештаја [...] }\end{array}$ \\
\hline Мк & $\begin{array}{l}{[\ldots] \text { а откако се запалија контролните ламби по вклучувањето на }} \\
\text { главниот прекинувач, излегов од тесната внатрешност }[\ldots]\end{array}$ \\
\hline Бг & $\begin{array}{l}{[\ldots] \text { и щом контролните лампи светнаха при включването на }} \\
\text { главната верига, излязох от тясната кабина [...] }\end{array}$ \\
\hline
\end{tabular}

Бросается в глаза выбор македонского союза откако из группы 'после того как'. У этого союза необычайно широкий диапазон употребления. Как было отмечено уже в сноске 5, он может выражать не только темпоральное значение 'после того как', но также значение 'с тех пор как'. Приведенный пример показывает, что он может выражать также значение 'когда' .

Приведенные в (4)-(6) примеры показывают, что союзы с̆іm, иим, штмо, щцом (и отчасти также откако) могут выражать чисто таксисное значение контактного предшествования, соответствующее значению союзам как только и jak tylko в русском и польском языках.

Переходим к рассмотрению нетемпорального употребления союзов типа 'как только'.

(7) Булгаков. Союзы штом и щюм с нетемпоральным значением:

\begin{tabular}{|l|l|}
\hline Ру & $\begin{array}{l}\text { [Профессор категорически утверждал, что сейчас, по крайней } \\
\text { мере в данный момент, никаких признаков рака у буфетчика } \\
\text { нет.] Но что раз так ... Раз он боится и какой-то шарлатан его } \\
\text { напуzал, то нужно сделать все анализы... }\end{array}$ \\
\hline По2 & $\begin{array}{l}{[\ldots] \text { ale skoro tak... skoro się boi i jakiś szarlatan go nastraszyt, }} \\
\text { bardzo sie obawia raka, to trzeba zrobić wszelkie analizy... }\end{array}$ \\
\hline Сн & $\begin{array}{l}{[\ldots] \text { ker pa je že... ker se boji in ker ga je neki mazač prestrašil, je }} \\
\text { nujno narediti vse analize... }\end{array}$ \\
\hline Xp & $\begin{array}{l}{[\ldots] \text { ali ako je tako... ako se boji i ako ga je uplašio neki šarlatan, }} \\
\text { onda mora izvršiti sve analize... }\end{array}$ \\
\hline
\end{tabular}




\begin{tabular}{|l|l|}
\hline Сб1 & $\begin{array}{l}{[\ldots] \text { кад ствари већ тако стоје... када се он толико боји и када га }} \\
\text { је некакав шарлатан толико престрашио, потребно је извршити } \\
\text { све анализе... }\end{array}$ \\
\hline Сб2 & $\begin{array}{l}{[\ldots] \text { али, ако је тако... ако се боји и некакав га је шарлатан }} \\
\text { наплашио, онда треба направити све анализе... }\end{array}$ \\
\hline Мк & $\begin{array}{l}{[\ldots] \text { но штом } е \text { така... штом тој се плаши, некој шарлатан штом }} \\
\text { толку го наплашил, нека ги направи сите анализи... }\end{array}$ \\
\hline Бг1/2 & $\begin{array}{l}{[\ldots] \text { но шом } е \text { така... щом се страхува и някакъв шарлатанин го } e} \\
\text { уплашил, трябва да се направят всички проби... }\end{array}$ \\
\hline
\end{tabular}

В данном примере македонский штом и болгарский щзом соответствуют союзам paз, skoro, ker и ако с причинным или условным значением в других языках. ${ }^{7}$

В хорватском и двух сербских переводах текста Булгакова нетемпоральное употребление союзов с̌im и чим не представлено. Однако на возможность подобного употребления сербского чим указывает первый из двух сербских переводов следующего фрагмента из романа Лема:

(8) Lem. Союзы чим, штом и щцом с нетемпоральным значением:

\begin{tabular}{|c|c|}
\hline По & $\begin{array}{l}\text { Skoro dziejá się takie rzeczy - pomyślałem - to może i Fechnera uda } \\
\text { mi się znaleźć. }\end{array}$ \\
\hline Py & $\begin{array}{l}\text { Раз уж происходят такие вещи, подумал я, то, может быть, и } \\
\text { Фехнера удастся найти. }\end{array}$ \\
\hline $\mathrm{CH}_{\mathrm{H}}$ & $\begin{array}{l}\text { Če se že dogajajo take stvari, sem pomislil, mi bo mogoče uspelo najti } \\
\text { tudi Fechnerja. }\end{array}$ \\
\hline $\mathrm{Xp}$ & $\begin{array}{l}\text { S obzirom da se događaju takve stvari - pomislio sam - možda ću } \\
\text { uspjeti pronaći i Fechnera. }\end{array}$ \\
\hline Сб1 & $\begin{array}{l}\text { Чим се дешавају такве ствари - помислио сам - можда ћу успети } \\
\text { да пронађем Фехнера. }\end{array}$ \\
\hline Сб2 & $\begin{array}{l}\text { Пошто се такве ствари догађају - помислио сам - možda } ћ y \\
\text { успети да пронађем и Фехнера. }\end{array}$ \\
\hline Мк & $\begin{array}{l}\text { Штом се случуваат вакви работи - си помислив - тогаш можеби } \\
\text { ке ми успее да го најдам Фехнер. }\end{array}$ \\
\hline
\end{tabular}

${ }^{7}$ В первом сербском переводе используется неспециализированный союз кад(a). См. также пример (9), где подобное употребление этого союза представлено в другом сербском переводе. Тот факт, что союз кад(a) дополнительно может выражать причинное или условное значение, отмечен в указанной выше работе (Поповић 2014: 138; 148-149). Нижеприведенный пример (9) показывает, что такое употребление аналогичных союзов представлено также в хорватском, македонском и словенском. К сожалению рамки статьи не позволяют рассматривать такие случаи. 


\begin{tabular}{|l|l|}
\hline Бг & $\begin{array}{l}\text { Щом стават такива неща - мислех си а3, - може пък да намеря } \\
\text { Фехнер. }\end{array}$ \\
\hline
\end{tabular}

Бросается в глаза, что во втором сербском переводе выбран союз пошто, который по первичному темпоральному значению относится к союзам со значением 'после того как'8. Это, пожалуй, указывает на то, что при нетемпоральном употреблении взаимозаменяемость союзов из указанных двух групп может реализоваться легче, чем при темпоральных вариантах значения. На это указывает и следющий пример, где в одном из двух болгарских переводов также выбран союз из группы 'после того как', а в македонском переводе (как и в словенском, хорватском и одном из сербских переводов) употребляется неспециализированный союз типа когда:

(9) Булгаков. Союзы щцом, след като и кога с нетемпоральным значением:

\begin{tabular}{|c|c|}
\hline Py & $\begin{array}{l}\text { А как же попал в кабинет переводчик, если на дверях была } \\
\text { печать?! }\end{array}$ \\
\hline По1 & $\begin{array}{l}\text { A w jaki sposób tłumacz dostał się do gabinetu, skoro na drzwiach } \\
\text { znajdowała się nienaruszona pieczęć? }\end{array}$ \\
\hline $\mathrm{CH}$ & Kako pa je prevajavec prišel v delovno sobo, ko je bil na vratih pečat?! \\
\hline $\mathrm{Xp}$ & A kako je prevodilac dospio u kabinet kad je na vratima bio pečat?! \\
\hline Сб1 & $\begin{array}{l}\text { А како се тај преводилац створио у кабинету ако је на вратима био } \\
\text { печат? }\end{array}$ \\
\hline Сб2 & $\begin{array}{l}\text { Али како је преводилац доспео у кабинет, кад су врата била } \\
\text { запечаћена?! }\end{array}$ \\
\hline Мк & $\begin{array}{l}\text { А како можел преведувачот да се најде во кабинетот кога на } \\
\text { вратата имаше печат?! }\end{array}$ \\
\hline Бг1 & $\begin{array}{l}\text { [...] ами как се е озовал в кабинета този преводач, след като на } \\
\text { вратата имаше печат?! }\end{array}$ \\
\hline Бг 2 & $\begin{array}{l}\text { Но как преводачът е влязъл в кабинета, щом на вратата имаше } \\
\text { печат?! }\end{array}$ \\
\hline
\end{tabular}

Отметим, что в македонских переводах текста Булгакова союз штом был представлен значительно реже чем аналогчный союз щзом в двух болгарских переводах. Как и в сербских параллельных переводах, нередко встречается также обычный условный союз ако 'если’, как в следующем примере:

(10) Булгаков. Болгарский союз щцом с нетемпоральным значением наряду с македонским условным союзом ако:

\footnotetext{
${ }^{8}$ См. ниже примеры (16)-(18) с нетемпоральным употреблением этого типа союзов.
} 


\begin{tabular}{|c|c|}
\hline Py & $\begin{array}{l}\text { Зачем же Варенуха шел в кабинет финдиректора, ежели полагал, } \\
\text { что его там нету? }\end{array}$ \\
\hline По1 & $\begin{array}{l}\text { Więc po co Warionucha szedt do gabinetu dyrektora finansowego, } \\
\text { skoro sqdzit, że go tam nie ma? }\end{array}$ \\
\hline $\mathrm{CH}_{\mathrm{H}}$ & $\begin{array}{l}\text { Zakaj je Varenuha prišel v delovno sobo finančnega ravnatelja, če je } \\
\text { domneval, da njega ni tam? }\end{array}$ \\
\hline $\mathrm{Xp}$ & $\begin{array}{l}\text { Zašto je Varenuha došao u kabinet findirektora ako je mislio da ga } \\
\text { tamo nema? }\end{array}$ \\
\hline Сб1/2 & $\begin{array}{l}\text { Зашто је Варенуха ушао у кабинет финансијског директора ако } \\
\text { је сматрао да он није ту? }\end{array}$ \\
\hline Мк & $\begin{array}{l}\text { Зошто Варенуха одел во кабинетот на финансискиот директор } \\
\text { ако мислел дека тој не е таму? }\end{array}$ \\
\hline Бг1 & $\begin{array}{l}\text { Защо Варенуха се е запътил за кабинета на финдиректора, щом } \\
\text { е предполагал, че него го няма? }\end{array}$ \\
\hline Бг $2^{9}$ & $\begin{array}{l}\text { Защо Варенуха щ̧е влиза в кабинета му, щом предполага, че го } \\
\text { няма? }\end{array}$ \\
\hline
\end{tabular}

Как будет указано в разделе 3, в рассматриваемых переводах нетемпоральное употребление болгарского союза щзом представлено шире, чем у аналогичного македонского союза штом. Это можно, пожалуй, отнести к ряду других явлений, указывающих на промежуточное положение македонского языка между болгарским и сербским.

Приведенные выше примеры (7)-(10) показывают, что союзы щзом и (реже) штом могут естественно выражать нетемпоральное значение типа русского если и раз.

В наших двух исходных текстах нетемпоральное употребление сербского союза чим было найдено только в тексте Лема, см. (8). В этом тексте из 8 употреблений этого союза даже целых 6 относятся к нетемпоральному типу. ${ }^{10} \mathrm{~A}$ в хорватском переводе (как и во втором сербском) есть только два случая употребления аналогичного союза čim, и только в темпоральном употреблении. Отметим, что в хорватских переводах наших двух исходных текстов нетемпоральное употребление союза с̌im вообще не было найдено. Но на то, что такое употребление в хорватском все же встречается, указывает следующий пример из перевода романа The Hitchhiker's Guide to the Galaxy Дугласа Адамса:

${ }^{9}$ В данном варианте использованы другие временные формы: настоящее время в ПЧ и будущее время в ГЧ.

${ }^{10}$ Во втором сербском переводе союз чим представлен только 2 раза, оба в темпоральном значении. В соответствиях с шестью случаями нетемпорального употребления союза чим в первом переводе было найдено 3 раза пошто (как в примере (8) и 3 раза кад. Такие различия указывают на то, что выбор союзов в значительной степени может зависеть от личного стиля автора или переводчика. 
(11) Valjda je ovakve stvari voljelo dosta ljudi, čim su stavljene u prodajni katalog.

'Очевидно такие вещи любили достаточно много людей, если они включены в каталог.' 11

Причинное употребление союза с̌im представлено также в хорватско-нидерландском словаре под редакцией Радована Лучича (Lučić 2013):

(12) Čim tako često zove, znam da mu nešto treba.

'Поскольку он так часто звонит, я знаю, что ему что-то нужно.'

В общем можно сказать, что возможность нетемпорального употребления союзов чим или с̌im нельзя отрицать, хотя в нашем материале частотность этого явления низкая ${ }^{12}$.

В то же время подобное употребление словенского союза с̌im вообще не было обнаружено.

В завершение этой части статьи отметим, что интерпретации логической обусловленности у хорватского с̌im, сербского чим, македонского штом и болгарского щзом, как правило, сопутствует наличие в СПП комбинации видовременных форм, которая стандартно исключает выражение значения предшествования типа 'как только'. В то время, как у этих союзов темпоральное значение стандартно выражается формами глаголов СВ в обеих частях СПП, при нетемпоральном значении встречаются как раз глаголы НСВ в одной или обеих частях.

\section{2. Союзы типа 'после того как'}

Переходим к рассмотрению союзов типа 'после того как'

(13) Lem. Сербский, македонский и болгарский союзы пошто, откако и след като с темпоральным значением.

\begin{tabular}{|l|l|}
\hline По & $\begin{array}{l}\text { Berton }[\ldots] \text { wróciwszy do pozornej równowagi nie chciat ani na chwilę } \\
\text { opuścić wnętrza głównej rakiety [...] }\end{array}$ \\
\hline Ру & $\begin{array}{l}\text { Бертон }[\ldots] \text { вернувшись к кажущемуся равновесию, не хотел ни на } \\
\text { минуту выйти из главной ракеты [... }\end{array}$ \\
\hline $\mathrm{CH}$ & $\begin{array}{l}\text { Berton }[\ldots] \text { po tem, ko se mu je na videz povrnilo duševno ravnovesje, } \\
\text { ni hotel niti za hip zapustiti notranjosti glavne rakete }[\ldots]\end{array}$ \\
\hline $\mathrm{Xp}$ & $\begin{array}{l}\text { Berton }[\ldots] \text { prividno } \text { povrativši ravnovjesje nije htio ni na trenutak } \\
\text { napuštati glavnu raketu }[. . .]\end{array}$ \\
\hline
\end{tabular}

${ }^{11}$ В оригинале: Presumably enough people must have liked this sort of thing to make it a paying proposition. В хорватском, сербском и македонском переводах выбрана общая тактика и вместо 'чтобы внести их в каталог' там употребляется конструкция 'если/раз они включены в каталог'.

${ }^{12}$ См. ниже таблицу в разделе 3. 


\begin{tabular}{|l|l|}
\hline Сб1/2 & $\begin{array}{l}\text { Бертон, пошто се вратио у привидну равнотежу, није хтео ни за } \\
\text { тренутак да напусти унутраност главне [...] ракете [...] }\end{array}$ \\
\hline Мк & $\begin{array}{l}{[\ldots] \text { откако привидно се вратил во рамнотежа, не сакал ниту за }} \\
\text { миг да ја напушти внатрешноста на главната ракета [... }\end{array}$ \\
\hline Бг & $\begin{array}{l}\text { Бертон [...] след като душевното му равновесие се възстановило } \\
\text { привидно, не искал нито за миг да излезе вън от главната ракета }[. . .]\end{array}$ \\
\hline
\end{tabular}

Этот пример показывает часто встречающееся соответствие ПЧ с временным союзом и конструкции с деепричастнием СВ (здесь в польском оригинале и русском и хорватском переводах). Такое соответствие очень ярко проявляется в македонском переводе Булгакова, где 117 из 135 примеров с союзом откако соответствует деепричастию СВ в оригинале. ${ }^{13}$ Следующий пример показывает, что рассматриваемые союзы могут также соответствовать русскому союзу после того как.

(14) Булгаков. Темпоральное употребление союзов пошто, откако и след като.

\begin{tabular}{|l|l|}
\hline Ру & $\begin{array}{l}\text { Моя охрана упустила его вечером на базаре после того, как он } \\
\text { покинул дворец Каифы. }\end{array}$ \\
\hline По2 & $\begin{array}{l}\text { Моja ochrona zgubiła go wczoraj na bazarze, po tym jak opuścit pałac } \\
\text { Kajfasza. }\end{array}$ \\
\hline $\mathrm{CH}$ & $\begin{array}{l}\text { Moji ljudje so ga zvečer na bazarju spustili iz oči, po tistem, ko je } \\
\text { zapustil Kajfovo palačo. }\end{array}$ \\
\hline $\mathrm{Xp}$ & $\begin{array}{l}\text { Moja straža ga je izgubila sinoć na tržnici nakon što je napustio Kajfin } \\
\text { dvorac. }\end{array}$ \\
\hline Сб1/2 & $\begin{array}{l}\text { Моја стража га jе испустила из вида синоћ на тржници, пошто je } \\
\text { напустио Кајафин дворац. }\end{array}$ \\
\hline Мк & $\begin{array}{l}\text { Мојата стража го изгуби вечерта на пазарот, откако тој го беше } \\
\text { напуштил дворецот на Каифа. }\end{array}$ \\
\hline Бг & $\begin{array}{l}\text { Моята охрана го е изпуснала от очи снощи на пазара, след като } \\
\text { той излязъл от двореца на Каиафа. }\end{array}$ \\
\hline
\end{tabular}

Оказалось, что в обоих наших «исходных текстах» нет ни одного случая употребления хорватского союза pošto. Однако в других текстах союз pošto достаточно широко представлен в темпоральном употреблении:

(15) Tolkien (Hobbit). Хорватский союз pošto с темпоральным значением: \begin{tabular}{|l|l|}
\hline Анг & $\begin{array}{l}\text { "Come along in, and have some tea!” he managed to say after taking a } \\
\text { deep breath. }\end{array}$ \\
\hline
\end{tabular}

${ }^{13}$ Аналогичная ситуация существует в болгарских текстах. Это показывает, что значительные различия между славянскими языками в употребляемости деепричастий могут сильно влиять на употребление таксисных союзов. 


\begin{tabular}{|c|c|}
\hline Py & $\begin{array}{l}\text { - Заходите, выпейте чаю! - ухитрился он вылавить наконец, } \\
\text { набрав воздуху в лёгкие. }\end{array}$ \\
\hline По & $\begin{array}{l}\text { - Wejdź, proszę, i poczęstuj się herbatą! - dodat, odetchnawszy } \\
\text { głęboko. }\end{array}$ \\
\hline $\mathrm{CH}_{\mathrm{H}}$ & $\begin{array}{l}\text { "Le kar vstopite, čaj je že na mizi!" mu je uspelo spraviti iz sebe, ko je } \\
\text { globoko zajel sapo. }\end{array}$ \\
\hline $\mathrm{Xp}$ & $\begin{array}{l}\text { - Izvolite unutra na čaj! - uspio je izustiti pošto je bio duboko udahnuo } \\
\text { zrak. }\end{array}$ \\
\hline Сб & $\begin{array}{l}\text { "Изволите уђите, чај је послужен!”, успело му да изговори nakon } \\
\text { što је дубоко удахнуо ваздух. }\end{array}$ \\
\hline Мк & “Влези и послужи се со чај!” успеа да каже откако зеде здив. \\
\hline Бг & $\begin{array}{l}\text { - Заповядай да пийнеш чаша чай - успя да каже той, след като си } \\
\text { пое дълбоко дъх.. }\end{array}$ \\
\hline
\end{tabular}

И здесь в русском и польском соответствиях выбрано деепричастие СВ.

Переходим к рассмотрению нетемпорального употребления союзов типа 'после того как'.

Нетрудно найти такие примеры с сербским союзом пошто. В тексте Булгакова, например, 17 из 38 случаев имеет нетемпоральное значение. В соответствиях обычно употребляется ПЧ с причинным союзом.

(16) Булгаков. Сербский союз пошто с нетемпоральным значением:

\begin{tabular}{|l|l|}
\hline Ру & $\begin{array}{l}\text { [Финдиректор] отправился за кулисы, чтобы принимать } \\
\text { гастролера, так как более принимать было некому. }\end{array}$ \\
\hline По & $\begin{array}{l}\text { [Dyrektor] wybrat się za kulisy, żeby przyjąć gościa, ponieważ nie } \\
\text { miat już kto go przyjąć. }\end{array}$ \\
\hline Cн & $\begin{array}{l}\text { [Finančni ravnatelj] se odpravil za kulise, da sprejme nastopajočega } \\
\text { gosta, ker ni bilo nikogar drugega, da bi ga lahko sprejel. }\end{array}$ \\
\hline Xp & $\begin{array}{l}\text { Findirektor [...] uputio se iza kulise da primi gosta, jer nije bilo nikog } \\
\text { drugog da to učini. }\end{array}$ \\
\hline Сб1/2 & $\begin{array}{l}\text { Финансијски директор [...] nође иза кулиса да сачека госта, пошто } \\
\text { не беше никог другог ко би га дочекао. }\end{array}$ \\
\hline Мк & $\begin{array}{l}\text { Финансискиот директор [...] тргна зад кулисите за да го пречека } \\
\text { гостинот, зашто немаше никој друг што би го направил тоа. }\end{array}$ \\
\hline Бг & $\begin{array}{l}\text { Финдиректорьт [...] тръгна към кулисите да посрещне гостуващия } \\
\text { артист, защото нямаше кой друг да го посрещне. }\end{array}$ \\
\hline
\end{tabular}


(17) Lem. Сербский союз пошто с нетемпоральным значением:

\begin{tabular}{|l|l|}
\hline Ру & $\begin{array}{l}\text { Точнее, ситуация была гораздо хуже, потому что труд всех этих } \\
\text { лет оказался напрасным. }\end{array}$ \\
\hline По & $\begin{array}{l}{[\ldots] \text { właściwie sytuacja jest o wiele gorsza, ponieważ cały trud tych lat }} \\
\text { okazat się daremny. }\end{array}$ \\
\hline $\mathrm{CH}$ & $\begin{array}{l}{[\ldots] \text { pravzaprav pa je položaj še precej slabši, saj se je pokazalo, da je }} \\
\text { bil ves trud teh let zaman. }\end{array}$ \\
\hline $\mathrm{Xp}$ & $\begin{array}{l}{[\ldots] \text { a situacija je zapravo puno lošija, budući da se sav napor tih }} \\
\text { godina pokazao uzaludnim. }\end{array}$ \\
\hline Сб1/2 & $\begin{array}{l}{[\ldots] \text { у ствари je ситуација била далеко гора, пошто ce цео труд тих }} \\
\text { година показао као узалудан. }\end{array}$ \\
\hline Мк & $\begin{array}{l}{[\ldots] \text { всушност, ситуацијата } е \text { многу полоша, бидејќи сиот труд на }} \\
\text { тие години се покажа залуден. }\end{array}$ \\
\hline Бг & $\begin{array}{l}\text { Всъщност положението беше още по-лошо, зашото целият труд } \\
\text { през тия години се бе оказал напразен. }\end{array}$ \\
\hline
\end{tabular}

Эти примеры относятся к часто встречаемому типу, в котором только в сербских вариантах нетемпоральное значение выражается союзом из группы 'после того как’, в то время как в других славянских вариантах, включая хорватский, употребляются обычные причинные союзы. Оказалось, что если в сербских текстах исходного материала союз пошто часто употребляется с нетемпоральным значением, в большинстве хорватских текстов очень трудно найти надежные примеры такого типа. Приводим один из редких надежных примеров:

(18) Tolkien (Ring). Нетемпоральное употребление хорватского союза pošto:

\begin{tabular}{|l|l|}
\hline Анг & $\begin{array}{l}\text { But after a time, as Frodo did not show any sign of writing a book on the } \\
\text { spot, the hobbits returned to their questions about doings in the Shire. }\end{array}$ \\
\hline Ру & $\begin{array}{l}\text { Но через некоторое время, поскольку Фродо не собирался писать } \\
\text { книгу на месте, хоббиты вернулись к своим расспросам об Уделе. }\end{array}$ \\
\hline По & $\begin{array}{l}\text { Ponieważ jednak Frodo żadnym gestem nie zdradzit, ze gotów jest na } \\
\text { miejscu zasiąś do pisania swojego dzieła, hobbici powrócili } \text { do pytań } \\
\text { о wydarzenia w Shire }\end{array}$ \\
\hline Сн & $\begin{array}{l}\text { Ampak čez čas, ko Frodo ni z nobenim znamenjem pokazal, da } \\
\text { bi nameraval knjigo spisati kar pri priči, so se hobiti spet vrnili } \mathrm{k} \\
\text { vprašanjem o tem, kaj se dogaja na Šajerskem. }\end{array}$ \\
\hline Хр & $\begin{array}{l}\text { Ali nakon nekog vremena, pošto Frodo nije pokazivao namjeru } \\
\text { da počne smjesta pisati knjigu, hobiti su se nastavili raspitivati o } \\
\text { zbivanjima u Shireu. }\end{array}$ \\
\hline Сб & $\begin{array}{l}\text { Aли после неког времена, пошто Frodo nije pokazao nikakav } \\
\text { znak pisanja knjige na licu mesta, Hobiti se vratiše raspitivanjima o } \\
\text { događajima u Okrugu. }\end{array}$ \\
\hline
\end{tabular}




\begin{tabular}{|l|l|}
\hline Мк & $\begin{array}{l}\text { Но по извесно време, бидејќ Фродо не покажуваше никаков знак } \\
\text { на пишување книга на самото место, Хобитите му се вратија на } \\
\text { распрашувањето за настаните во Шаер. }\end{array}$ \\
\hline Бг & $\begin{array}{l}\text { Но тъй като Фродо не проявяваше намерение тутакси да напише } \\
\text { книгата, хобитите постепенно се върнаха към въпросите за } \\
\text { събитията из Графството. }\end{array}$ \\
\hline
\end{tabular}

Здесь только в словенском переводе употребляется неспециализированный союз типа когда. В других переводах ясно выражается значение причины. В данном случае употребление союзов роšto и пошто совпадает, но, как сказано выше, в нашем материале такие случаи встречаются крайне редко.

Бросается в глаза, что в македонском и болгарском переводах всех трех приведенных примеров не употребляются союзы из группы 'после того как' Отметим, что нам не удалось найти ни одного примера нетемпорального употребления македонского союза откако. Может быть, это связано с указанным выше очень широким употреблением этого союза в чисто таксисных СПП. Что касается болгарского союза след като, можно, пожалуй, сказать то же самое, что и у хорватского союза pošto: видимо нетемпоральное значение не исключается, но в нашем материале редко встречается. См. следующий пример: ${ }^{14}$

(19) Orwell. Болгарский союз след като с нетемпоральным значением:

\begin{tabular}{|l|l|}
\hline Анг & $\begin{array}{l}\text { Since each of the three super-states is unconquerable, each is in effect a } \\
\text { separate universe [...] }\end{array}$ \\
\hline Ру & $\begin{array}{l}\text { Поскольку сверхдержавы непобедимы, каждая представляет } \\
\text { собой отдельную вселенную [...] }\end{array}$ \\
\hline По & $\begin{array}{l}\text { Skoro każde z mocarstw jest niepokonane, każde w efekcie tworzy } \\
\text { odrębny świat [...] }\end{array}$ \\
\hline Сн & $\begin{array}{l}\text { Ker } j e \text { vsaka od treh superdržav nepremagljiva, je pravzaprav vsaka svet } \\
\text { zase [...] }\end{array}$ \\
\hline Хр & $\begin{array}{l}\text { Budući da je svaka od triju supersila nepobjediva, svaka je zapravo } \\
\text { poseban svijet [...] }\end{array}$ \\
\hline Сб & $\begin{array}{l}\text { Pošto je svaka od ove tri superdržave nepobediva, svaka je u stvari } \\
\text { poseban svet [...] }\end{array}$ \\
\hline Мк & $\begin{array}{l}\text { Бидејќи секоја од овие три држави } е \text { непобедлива, всушност секоја } \\
\text { од нив } е \text { посебен свет [...] }\end{array}$ \\
\hline Бг & $\begin{array}{l}\text { След като всяка от трите супердържави } е \text { непобедима, всяка от тях } \\
\text { и отделна вселена [...] }\end{array}$ \\
\hline
\end{tabular}

${ }^{14}$ См. также пример (9). В главе о болгарском таксисе в уже упомянутой еще не опубликованной коллективной монографии на нетемпоральное употребление этого союза указывает Руселина Ницолова. 
Таким образом делаем вывод, что нетемпоральное значение могут выражать все расматриваемые нами союзы, кроме македонскога откако.

\section{3. Обзор количественных соотношений}

Наш анализ показал, что примеры с таксисными союзами предшествования во вторичных значениях есть в большинстве южнославянских языков: сербском, хорватском, македонском и болгарском. В словенской части нашего материала такое употребление соответствующих союзов не было найдено. ${ }^{15}$

Работа с параллельными текстами показала нам, что частотность употребления данных союзов заметно варьируется. Чтобы получить некоторое представление об этом, была более детально проанализирована одна треть нашего исходного материала -7 текстов с общим объемом около полумиллиона словоупотреблений (в русской части). В следующих таблицах указывается общее количество употреблений каждого рассматриваемого союза плюс количество случаев с нетемпоральным значением.

Союзы из группы 'как только'

\begin{tabular}{|l|c|c|c|c|c|c|c|c|}
\hline & \multicolumn{2}{|c|}{ Хр } & \multicolumn{2}{c|}{ Сб } & \multicolumn{2}{c|}{ Мк } & \multicolumn{2}{|c|}{ Б } \\
\hline & с̌im & нетемп. & чим & нетемп. & штом & нетемп. & щом & нетемп. \\
\hline Adams & 8 & 1 & 7 & 1 & 6 & 1 & 19 & 10 \\
\hline Brown & 8 & 0 & 6 & 0 & 11 & 1 & 34 & 19 \\
\hline Булгаков & 10 & 0 & 12 & 0 & 17 & 1 & 21 & 12 \\
\hline Carroll & 23 & 0 & 43 & 0 & 38 & 8 & 88 & 22 \\
\hline Lem & 2 & 0 & 8 & 6 & 13 & 12 & 23 & 17 \\
\hline Orwell & 30 & 0 & 21 & 0 & 2 & 0 & 32 & 10 \\
\hline Süskind & 10 & 0 & 10 & 0 & 18 & 3 & 47 & 20 \\
\hline Bceго & 91 & $1(1 \%)$ & 107 & $7(6,5 \%)$ & 105 & $26(25 \%)$ & 264 & $110(42 \%)$ \\
\hline
\end{tabular}

Союзы из группы 'после того как'

\begin{tabular}{|l|c|c|c|c|c|c|c|c|}
\hline & \multicolumn{2}{|c|}{ Хр } & \multicolumn{2}{c|}{ Сб } & \multicolumn{2}{c|}{ Мк } & \multicolumn{2}{c|}{ Бг } \\
\hline & роšto & нетемn. & пошто & нетемn. & откако & нетемп. & след като & нетемп. \\
\hline Adams & 6 & 6 & 14 & 7 & 11 & 0 & 14 & 0 \\
\hline Brown & 0 & 0 & 2 & 1 & 57 & 0 & 29 & 9 \\
\hline Булгаков & 0 & 0 & 38 & 17 & 135 & 0 & 53 & 2 \\
\hline Carroll & 1 & 0 & 33 & 30 & 2 & 0 & 11 & 0 \\
\hline Lem & 0 & 0 & 26 & 20 & 26 & 0 & 12 & 0 \\
\hline Orwell & 0 & 0 & 50 & 40 & 23 & 0 & 43 & 10 \\
\hline Süskind & 24 & 0 & 12 & 10 & 43 & 0 & 32 & 0 \\
\hline Bceго & 31 & $6(19 \%)$ & 171 & $125(73 \%)$ & 297 & 0 & 194 & $21(11 \%)$ \\
\hline
\end{tabular}

15 Это не удивляет, поскольку различия проявляются и в других областях, например в употреблении видов глагола. 
Данные, представленные в таблице указывают на существование заметных различий между исследуемыми языками. ${ }^{16}$ В то время как в юго-восточных языках (болгарском и македонском) расширенное значение в основном (или исключительно - в македонском) наблюдается у союзов типа 'как только', в сербском и хорватском преобладают союзы типа 'после того как'. Бросается в глаза значительное различие в частотности между союзами noumo и pošto в близкородственных сербском и хорватском языках. ${ }^{17}$ Некоторые различия в таблице указывают на то, что важным фактором может быть характер текста и персональный стиль автора/переводчика.

\section{3. Заключение}

Анализ приведенных примеров показывает, что появление вторичного причинного или условного значения у временных союзов маркируется главным образом сменой совокупности глагольных форм в ПЧ и в ГЧ. Данные рассмотренных языков, а также аналогичные примеры из других языков свидетельствуют о том, что в принципе вторичное причинное или условное значение могут приобретать любые временные союзы, кроме тех, которые выражают таксисное значение следования. При этом можно предполагать, что наиболее часто вторичные значения приобретают союзы, имеющие значение 'когда', 'только что', 'после того как' и 'с тех пор как'18.

В заключение обратим внимание на следующее обстоятельство. Если наличие вторичного причинного или условного значения у временных (таксисных) союзов распространенное и вполне объяснимое явление, то нам неизвестны случаи, когда бы исходно причинный или условный союз утрачивал свое значение и становился бы временным союзом. Иными словами, утрата исходного причинного и условного значения в отличие от их появления у временных союзов противоречит эволюционным закономерностям развития языка.

${ }^{16}$ Желательно, конечно, проверить это на более широком материале, включая также материал из монолингвальных корпусов.

17 Это различие отмечено также в работе (Waldenfels et al. 2016: 25).

${ }^{18}$ Мнение, что у союзов с временны́м и причинным значениями последнее является вторичным, достаточно широко представлено в грамматической литературе. Однако нельзя не отметить, что по отношению к сербским союзам чим и пошто было высказано противоположное мнение известным сербским языковедом Михайло Стевановичем. (Благодарим анонимного рецензента за указание на это.) Стеванович утверждает, что у данных союзов временно́е значение можно подчеркивать через постановку фразового ударения на них и считает, что именно это указывает на вторичность этого значения (Стевановић 1974: 894, 897). Нам, однако, не ясно, как подобные акцентологические наблюдения могут влиять на установление примарности того или иного значения полисемантического слова в том смысле, как эти понятия были исползьованы в нашей статье, т.е. в смысле онтогенеза или исторического развития языка. 


\section{Использованная литература}

Евтюхин, Вячеслав Б. Группировка полей обусловленности: причина, условие, цель, следствие, уступка [В:] А. В. Бондарко (ред.) Теория функциональной грамматики: Локативность. Бытийность. Посессивность. Обусловленность. СанктПетербург: Наука, 1996, 138-174.

[Evtiukhin, Viacheslav B. Gruppirovka poleř obuslovlennosti: prichina, uslovie, tsel', sledstvie, ustupka [V:] A. V. Bondarko (red.) Teoriīa funktsional'noĭ grammatiki: Lokativnost'. Bytiīnost'. Posessivnost'. Obuslovlennost'. Sankt-Peterburg: Nauka, 1996, 138-174]

Князев, Юрий П. «Онтогенез отношений обусловленности в детской речи (по данным «Дневника» А. Н. Гвоздева)» [В:] Стелла Н. Цейтлин (ред.) Семантические категории в детской речи. Санкт-Петербург: Нестор-История, 2007, 339-358.

[Knízev, IUUrī̌ P. «Ontogenez otnosheniî obuslovlennosti v detskoĭ rechi (po dannym «Dnevnika» A. N. Gvozdeva)» [V:] Stella N. TSeittlin (red.) Semanticheskie kategorii v detskoŭ rechi. Sankt-Peterburg: Nestor-Istoriia, 2007, 339-358]

Подлесская, Вера И. «Импликативные конструкции: некоторые проблемы типологической классификации». Вопросы языкознания 6, 1995: 77-84.

[Podlesskaia, Vera I. «Implikativnye konstruktsii: nekotorye problemy tipologicheskoř klassifikatsii». Voprosy iazykoznaniīa 6, 1995: 77-84]

Поповић, Људмила. Контрастивна граматика српског и украјинског језика: таксис и евиденцијалност. Београд: Српска академија наука и уметности, 2014.

[Popović, Ljudmila. Kontrastivna gramatika srpskog i ukrajinskog jezika: taksis i evidencijalnost. Beograd: Srpska akademija nauka i umetnosti, 2014]

Стевановић, Михайло. Савремени српскохрватски језик. Граматички системи и књижевнојезичка норма II. Синтакса. Београд: Научна књига, 1974.

[Stevanović, Mihajlo. Savremeni srpskohrvatski jezik. Gramatički sistemi i književnojezička norma II. Sintaksa. Beograd: Naučna knjiga, 1974]

Сударева, Оксана Г. «Ранние этапы овладения детьми временных отношений и способов их языкового выражения» [В:] Стелла Н. Цейтлин (ред.) Семантические категории в детской речи. Санкт-Петербург: Нестор-История, 2007, 78-98.

[Sudareva, Oksana G. «Rannie ètapy ovladeniia det'mi vremennykh otnosheniñ i sposobov ikh iazykovogo vyrazheniia» [V:] Stella N. TSeětlin (red.) Semanticheskie kategorii v detskoĭ rechi. Sankt-Peterburg: Nestor-Istoriia, 2007, 78-98]

Храковский, Виктор С. «Таксис: семантика, синтаксис, типология». [В:] В. С. (ред.) Типология таксисных конструкций. Москва: Знак, 2009, 11-113.

[Xrakovskiǐ, Viktor S. «Taksis: semantika, sintaksis, tipologiia». [V:] V. S. (red.) Tipologiia taksisnykh konstruktsiĭ. Moskva: Znak, 2009, 11-113]

Givón, Thomas. Syntax: a functional-typological introduction. Vol. II. Amsterdam: Benjamins, 1990.

Lučić, Radovan. Woordenboek Kroatisch-Nederlands. Amsterdam: Pegasus, 2013.

Waldenfels, Ruprecht von, Maciej Eder. «A stylometric approach to the study of differences between standard variants of Bosnian/Croatian/Serbian, or: is the Hobbit in Serbian more Hobbit or more Serbian?» Russian Linguistics 40, 2016: 1-31. 
Тексты исходного материала ${ }^{19}$

Булгаков, Михаил. Мастер и Маргарита (1940 / 1973). Переводчики альтернативных переводов: Бг1: Лиляна Минкова; Бг2: Татяна Балова; По1: Irena Lewandowska \& Witold Dąbrowski; По2: Krzysztof Tur; Сб1: Милан Чопић; Сб2: Злата Коцић.

Островский, Николай. Как закалялась сталь (1932).

Adams, Douglas. The Hitchhiker's Guide to the Galaxy (1979).

Brown, Dan. The Da Vinci Code (2003).

Carroll, Lewis. Alice's Adventures in Wonderland (1865).

Collodi, Carlo. Le avventure di Pinocchio (1906).

De Saint-Exupéry, Antoine. Le petit prince (1943).

Eco, Umberto. Il nome della rosa (1980).

Frank, Anne. Het achterhuis. (1947 / 1991).

Hemingway, Ernest. The Old Man and the Sea (1952).

Herrigel, Eugen. ZEN in der Kunst des Bogenschießens (1948).

Kipling, Rudyard. The Jungle Book (1894).

Lem, Stanisław. Solaris (1961). Переводчики альтернативных переводов: Сб1 (не указан); Сб2: Predrag Obućina.

Milne, Alan A. Winnie-The-Pooh (1926).

Orwell, George. 1984 (1948).

Poe, Edgar A. The Murders in the Rue Morgue (1841).

Poe, Edgar A. The Black Cat (1843).

Rowling, Joanne. Harry Potter and the Philosopher's Stone (1997).

Tolkien, John R.R. The Hobbit or There and Back Again (1937) [Hobbit].

Tolkien, John R.R. The fellowship of the Ring $(1954,1966)$ [Ring].

Verne, Jules. Le tour du monde en quatre-vingt jours (1873).

Wells, Herbert G. The War of the Worlds (1898).

Адриан Барентсен, Виктор С. Храковски

\section{О СЕКУНДАРНОМ ЗНАЧЕЊУ ТАКСИСНИХ ВЕЗНИКА СА ЗНАЧЕЊЕМ ПРЕТХОЪЕЊА У СЛОВЕНСКИМ ЈЕЗИЦИМА}

\section{Резиме}

Познато је да везници с примарним временским, тачније таксисним значењем поседују потенцијал развијања секундарног узрочног или/и условног значења. Овај рад проучава на који начин овај потенцијал реализују поједини таксисни везници са значењем „чим““ и „пошто“ у четири словенска језика: српском, хрватском, бугарском и македонском. Теоријску основу истраживања чиниће поставке на којима се заснива колективна монографија Таксис y словенским језицима, чијом редакцијом се тренутно бавимо, док ће практичну основу

${ }^{19}$ Все тексты входят в Амстердамский параллельный корпус ASPAC. Для получения сведений о корпусе и о текстах просим обратиться к следующему адресу электронной почты: a.barentsen@xs4all.nl. 
представљати материјал Амстердамског паралелног корпуса (ASPAC), из ког је одабрано 23 текста с њиховим преводима на српски, хрватски, македонски и бугарски језик, као и на руски, пољски и словеначки. Примери са секундарним значењима постоје у већини истраживаних јужнословенских језика. Неки од њих се наводе у раду. Претежно су то примери из превода романа Михајла Булгакова (Majcmор и Маргарита) и Станислава Лема (Solaris), то су наши „полазни текстови“.

У таблици су представљени истраживани везници. У угластим заградама наведен је број примера истраживаних везника у нашем материјалу:

\begin{tabular}{|c|c|c|}
\hline Хрватски: & čim [333] / tek što & pošto $[370]$ / nakon što \\
\hline Српски: & чим [359] / тек што & noumo $[810]$ / nakon što \\
\hline Македонски: & штом $[435]$ / тукушто & откако [980] / откога \\
\hline Бугарски: & щцом [795] & след като [781] \\
\hline
\end{tabular}

Приближно једна трећина овог материјала истражена је детаљније, како би се одредила релативна учесталост случаја са секундарним значењем. У овом материјалу нису нађени једино примери с македонским везником откако. У другим трима језицима налазимо примере из обеју група. У српском и бугарском језику њихов укупан број је највиши и приближно једнак. Њихова дистрибуција по групама је, међутим, супротна: у српском изразито преовлађује пошто, тј. везник из друге групе, док у бугарском - щзм, из прве. У македонском секундарно значење је нађено само код одговарајућег везника штом, али у осетно мањем броју, него у бугарском. Хрватски језик, без обзира на његову велику блискост са српским, прилично се разликује од њега у смислу секундарне употребе истраживаних везника. У хрватском делу нашег материјала број оваквих примера је минималан.

Кључне речи: временски (таксисни) везници, антериорност, ширење значења, узрочно и условно значење, јужнословенски језици, упоредна анализа. 